\title{
Does Opaqueness Make Equity Capital Expensive for Banks?
}

\author{
Received: August 14, 2013 - Accepted: August 6, 2014 \\ Doi: dx.doi.org/10.12804/rev.econ.rosario.17.02.2014.01
}

\begin{abstract}
Karlo Kauko*
Bank of Finland
\end{abstract}

\begin{abstract}
Bank managers often claim that equity is expensive, which contradicts the Modigliani-Miller irrelevance theorem. An opaque bank must signal its solvency by paying high and stable dividends in order to keep depositors tranquil. This signalling may require costly liquidations if the return on assets has been poor, but not paying the dividend might trigger a run. A strongly capitalised bank should keep substantial amounts of risk-free yet non-productive currency because the number of shares is high, which is costly. The dividend is informative of the state of the bank; rational depositors react to it.
\end{abstract}

JEL Classification: G21, G35, D82

Keywords: dividends, bank capital, irrelevance theorem.

* Bank of Finland, PO Box 160, 00101 Helsinki, Finland; Phone +358 10 8312519; Fax +358 10831 2311; E-mail: karlo.kauko@bof.fi

Para citar este artículo: Kauko, K. (2014). Does Opaqueness Make Equity Capital Expensive for Banks? Revista de Economía del Rosario, 17(2), 203-227. doi: dx.doi.org/10.12804/rev.econ. rosario.17.02.2014.01 


\title{
¿Opacidad hace el capital patrimonial costoso para los bancos?
}

\author{
Resumen
}

Los banqueros habitualmente aseguran que el capital propio es costoso, lo que contradice el teorema de irrelevancia de Modigliani-Miller. Un banco opaco debe señalizar su solvencia al pagar dividendos altos y estables para mantener tranquilos a los depositantes. Esta señalización puede requerir costosas liquidaciones si el rendimiento sobre los activos ha sido pobre, pero no pagar estos dividendos podría provocar un pánico bancario. Un banco fuertemente capitalizado debe mantener una cantidad considerable de activos improductivos sin riesgo, dado que la cantidad de acciones es alta, siendo esto costoso. Los dividendos son informativos del estado del banco. Depositantes racionales reaccionan ante ellos.

Clasificación JEL: G21, G35, D82

Palabras clave: dividendos, capital bancario, teorema de irrelevancia.

\section{Faz opacidade caro capital patrimonial para os bancos?}

\section{Resumo}

Os banqueiros habitualmente asseguram que o capital próprio é custoso, o que contradiz o teorema de irrelevância de Modigliani-Miller. Um banco opaco deve sinalizar sua solvência pagando dividendos altos e estáveis para manter tranquilos aos depositantes. Esta sinalização pode requerer custosas liquidações se o rendimento sobre os ativos tem sido pobre, mas não pagar estes dividendos poderia provocar pânico bancário. Um banco fortemente capitalizado deve manter uma quantidade considerável de ativos improdutivos sem risco dado que a quantidade de ações é alta, sendo isto custoso. Os dividendos são informativos do estado do banco. Depositantes racionais reagem ante eles.

Classificação JEL: G21, G35, D82

Palavras-chave: dividendos, capital bancário, teorema da irrelevância 


\section{Introduction}

Banking differs from other industries in many ways. One of the most obvious differences is the funding structure. If one looks at the annual reports of companies in manufacturing or non-financial services, corporate debt almost never accounts for $90-97 \%$ of the balance sheet total. Such an extreme leverage is the norm rather than an exception among banks, and because of various off-balance sheet operations the true leverage is often even more extreme. If the government did not impose capital adequacy regulations on banks, capitalisation might be even weaker. Why is banking so different from other industries? Bank managers consider equity "expensive", but why does equity become more "expensive" in relative terms if it is used to finance loans instead of, say, machinery? This paper intends to present a potential explanation to this phenomenon.

The tendency to perceive equity "costly" seems to contradict the irrelevance theorem of Modigliani and Miller (1958). This theorem is based on a number of assumptions. For instance, it is assumed that the value of assets is not affected by the structure of the liability side of the balance sheet. This assumption is not necessarily valid in banking. Diamond (1984) proposes that debt on the balance sheet induces the banker to monitor debtors because no loan losses can be passed on to financiers. Diamond and Rajan (2001) propose that weak solvency may be a strategic commitment against debtors' attempts to renegotiate loan contracts. Calomiris and Kahn (1991) propose that depositors' possibility to make withdrawals might induce the banker not to abscond with the funds. Debt issued by banks has got both preferential fiscal treatment and implicit and explicit government guarantees, encouraging extreme leverage (Keeley 1990, Admati et al., 2010). The relative costs of debt and equity capital may not differ from other industries, but the cost of funding is more essential in financial intermediation than in, say, retail trade (see Hanson et al., 2011). Different explanations to bank aversion to strong capitalisation are not mutually exclusive.

Interestingly, this tendency to regard capital "expensive" has become stronger over time. In the past, banks used to have much more equity capital in relative terms, and obviously bank managers did not find equity particularly expensive. (See e.g. Åhman 1943 p. 70, Saunders \& Wilson 1999; Thies \& Gerlowski 1993) This change in the way of thinking may be due to implicit and explicit governmental safety nets, or, as will be proposed in the following, to the increasing opaqueness of modern banking.

This paper combines previous theories on bank runs and dividend signalling. The original Diamond-Dybvig (1983) model was intended to explain why and how banks convert short-maturity deposits to long-term investments, and what kinds of risks are involved. The idea of using dividends to signal pro- 
fitability was briefly discussed already by Miller and Modigliani (1961, p. 430), and a seminal theoretical contribution was presented by Bhattacharya (1979); paying dividends is wasteful because of tax reasons, but if paying them is less expensive for profitable firms than for less profitable ones, dividends are a credible signal, and they enhance the market value of the firm. Recent empirical evidence in favour of this approach is presented by e.g. Al-Yahyaee et al., (2011). Dividend cuts may be an especially adverse signal, and empirical evidence reviewed in section five indicates that avoiding them drives many companies' dividend policies.

Dividend cuts may have adverse signalling effects in any industry, but the effect is probably particularly strong in banking. There are two reasons for this.

1) Banks are inherently opaque. Rating agencies disagree on banks' creditworthiness more often than in the case of comparable companies in other industries (Iannotta, 2006; Morgan, 2002), and these disagreements have become more commonplace over time (Morgan, 2002). Further evidence on bank opaqueness is presented by e.g. Hirtle (2006). The absence of other sources of information increases the relative role of any available signal.

2) In no other industry the value of a company depends as strongly on how counterparties perceive it. Deposit runs can be triggered even by self-fulfilling expectations, let alone adverse signals. Deposit runs do not occur in mining and manufacturing.

When bank opaqueness is discussed, the focus is often on the asset side of the balance sheet, but even broadly understood bank liabilities have become opaque. For instance, many banks have established off-balance sheet investment vehicles, such as SIVs and conduits, that acquire loan funding in the market, but are effectively guaranteed by the sponsoring bank without being included in the publicly disclosed group balance sheet. If a bank arranges a commercial paper program and sells credit risk protection against defaults on this debt in the CDS market, it is effectively collecting short-maturity funding in order to finance its customer, and the bank does not dispose of the default risk. However, no additional debt is reported on the balance sheet.

These days even supervisors with their privileged access to confidential information often seem unable to assess the true leverage of banks. At least it is difficult to mention any pre-crisis initiatives of supervisors to regulate offbalance sheet vehicles. Increasing opaqueness must have some impact on the signalling value of whatever the bank does in the market.

Even though banks have no legal obligation to pay dividends, equity capital appears paradoxically about twice as expensive as debt in terms of cash flows. 
The OECD (2010, p. 11) published the list of the ten largest banks in the euro area in 2006. In the light of data found in annual reports, the non-weighted average ratio of dividends to the book value of shareholders' equity in this group was $8,7 \%$ in 2006, the last year before the financial crisis, and the median was $7,0 \%$. The annual average interest rate on non-collateralised three months interbank loans, the Euribor rate, was 3,1\% in 2006. In no bank of the sample the dividend yield on shareholders' equity was lower than this average money market rate. Hence, prior to the global financial crisis, the market was used to bank dividends higher than the rate of interest banks on bank debt, and paying something less would have been an adverse signal.

The model presented in this paper combines dividend signalling models and the Diamond-Dybvig bank run model. The bank needs to hold extra liquidity instead of illiquid yet return generating assets in order to be able to make large dividend payments; not doing so might trigger a deposit run. The dividend has got value as a Spencian signal because profitable institutions can finance larger payments than unprofitable ones. If the bank is opaque, it is not possible to say what the true leverage of the institution is, and observers pay attention to the easily observable dividend per share, not to the non-verifiable ratio of total dividends to risks or assets. The more equity has been issued, the more dividend payments the bank must be prepared to pay in total, which is costly.

Section two presents the assumptions of the model. Sections three and four analyse two different versions of the model. Section five compares the findings of the theoretical analysis and some previous empirical observations. Section six discusses the findings.

\section{Assumptions}

There is a bank. The bank is a monopoly. It can acquire funding from investors with two financial instruments.

1) Short-term deposits with a fixed interest rate.

2) Permanent equity capital.

There is a given number $(N, N>>0)$ of uncoordinated investors. The bank knows how numerous they are and where to find them. Each investor has got one unit of monetary savings to be invested in either bank equity or deposits. Each investor can also keep the sum as risk-free currency.

There are two kinds of investors. Type A investors know they will need no means of payment before the planned closure of the bank at stage five (see 
below). They accept both equity investments $(E)$ and deposit contracts $(D)$. Type B investors run the risk of being subject to a liquidity shock at stage four, and they do not accept equity because not consuming at an early stage would result in huge disutility. The number of type $B$ investors who may be subject to a liquidity shock is $N \Omega$, and the probability of a shock is $\lambda(0<\lambda<1)$ for each of them. The values on $N$ and $\Omega$ are not public knowledge but the value of $\lambda$ is. Investors of same type have completely identical preferences. In practice, parameters $N, \Omega$ and $\lambda$ determine how much liquidity shock related withdrawals the bank could expect under normal circumstances. One could assume that $\Omega$ is always +1 and could therefore be omitted, but if all investors run the risk of a liquidity shock nobody invests in bank equity unless equities can be sold at a later stage. A stock exchange and new investors entering the market should be assumed, or at least implicitly assumed.

It would be unrealistic to assume that the bank would know the probability of a liquidity shock better than the savers themselves; therefore $\lambda$ is publicly known. Instead, information on bank financiers is not observable without insider information. Therefore, it is meaningful to assume that omega is not publicly known but lambda is.

Things happen in the following order.

1) Funding; The bank observes what kinds of investment assets are available. It observes the realisation of the liquidation value $(Z, 0<Z<1)$ of available assets. This liquidation value is a random draw from a known distribution. Customers know the distribution $\mathrm{Z}$ is coming from, but not its value. The bank contacts privately each investor. The bank observes the type of each investor and offers either a deposit contract or the possibility to invest in equity. It chooses and publicly announces a fixed interest rate $\delta$ it promises to pay its depositors. An investor can either accept the offer of the bank or reject it. The bank knows how much debt it has issued but it cannot prove its funding structure.

2) Investments; The bank decides how much to invest in an illiquid yet productive asset and how much to keep as liquidity buffers $(L)$ consisting of risk-free currency with no return. The sum of investments $(I)$ and liquidity must equal the sum of equity and deposits $(I+L=E+D)$. The bank cannot prove to anyone the amount of investments it has made.

3) Returns realised; The bank privately learns the return on its investments but cannot credibly prove this information to anyone. In most cases, with probability $\theta$, the return on investments is normal, and the bank receives in cash the sum of the return $\alpha(0<\alpha<1)$ per one unit of investments. The values of $\theta$ and $\alpha$ are publicly known. With probability $1-\theta$ there is no return. 
4) Withdrawing; Each depositor is paid the interest rate $\delta(0<\delta<1)$ per one unit of deposits. The bank withdrawal desk opens. First, some type B investors notice they have been subject to a liquidity shock and they withdraw their savings. Second, dividends are paid. Third, remaining depositors observe the dividend. They become suspicious if the dividend is low; they no longer trust the bank and they decide to withdraw. Only non-suspicious depositors not subject to a liquidity shock will renew the deposit. If the bank has got an insufficient amount of currency ( $=L+$ return on assets) to pay interest payments and withdrawals, it is forced to sell some of its investment assets, or possibly all of them. The bank gets only $Z(0<Z<1)$ units of currency per one unit of liquidated assets. If the bank is unable to pay all withdrawals, those who come last to withdraw get nothing. The withdrawal desk is closed at the end of stage four.

5) End; Investments mature. Each unit of investments not liquidated at stage four is now worth the original investment 1 . If possible, depositors are paid the sum they deposited and again the interest rate $\delta$ per one unit of deposits. Any residual is divided between equity holders.

The rather extreme structure of the funding market is intended to be consistent with the concept of "cost of equity" for the bank. Irrespective of the instrument, the funding comes from the same source and the question is how to optimise the combination of equity and deposits. The real-life analogue of a depositor may be an institutional investor who has invested in short maturity instruments issued by an off-balance sheet vehicle guaranteed by the bank. ${ }^{1}$

The following assumptions on parameter values are made. It is never possible to pay all the withdrawals at stage four without liquidating assets if all the savings of investors have been invested at stage two $(\alpha<\Omega \lambda=>1>\Omega>\alpha / \lambda)$. It is never profitable to make an investment and to liquidate it at stage four because the sum of the return $\alpha$ and the value $Z$ of a liquidated investment is less than the original investment $1 .(1>Z+\alpha)$ No investor can invest in the asset directly. For instance, there might be a relatively large minimum investment no individual could make alone. The bank cannot offer any other types of financial contracts than above described short-term deposits and permanent equity.

1 One might also reinterpret the formal model by assuming that each investor has more than one unit of savings, and at least some of them know that they are going to need the share $\lambda$ of their savings at stage 1 and make some withdrawals. The maximum amount of equity would be $1-\lambda$ times the number of financiers. Savers would hold a portfolio consisting of both deposits and equity investments. The mathematics of the model would remain unaffected. 
The probability of the normal state is high. To be more precise, $\theta>\frac{1-Z}{1-Z+\alpha Z}$. As will be seen in the proof of proposition 2, at least in the first version of the model this condition induces the bank not to prepare itself for the unlikely event of bad times.

Two different versions of the model are analysed.

1) There may be an exogenously given dividend $\eta_{g}$. If the dividend is lower, a run takes place and all depositors try to withdraw. Both the bank and its customers know the value of $\eta_{g}$. This dividend is higher than any deposit rate the bank might offer $\left(\eta_{g}>\delta\right)$.

2) Alternatively, the probability of run $(r)$ is a decreasing function of the dividend $\eta$.

When depositors decide whether to renew the deposit at stage four, they react to the dividend per share, not to the total amount of dividends. This is a meaningful assumption if and only if the bank is so opaque that the true leverage of the institution is non-verifiable. Creditors do not know how many other creditors exist. If the bank issues more equity, no one can tell whether the bank reduces leverage or simply expands. If the bank were more transparent, financiers could calculate the amount of dividend payments per risk-weighted assets, which would be more indicative of the state of the bank.

The bank is risk neutral and it minimises $E(\psi)$, which is the expected value of the loss relative to the hypothetical case where the bank could simply invest all the savings of its financiers, issue nothing but equity and never liquidate anything at stage four, which would be possible if no financiers faced the risk of being subject to a liquidity shock $(\Omega=0)$. The loss $\psi$ consists of the expected value of unrealised revenue from undone investments $(\theta \alpha L)$ and the expected value of losses caused by premature liquidations of assets at stage four, which equals

$$
E(\psi)=\theta \alpha L+(1-Z) * E(H)
$$

where $H=$ premature asset liquidations. This objective function is relatively similar to the one used by Diamond and Dybvig (1983). Even Modigliani and Miller implicitly assumed that the company tries to maximise the market value of its liabilities. The value of bank liabilities is obviously a monotonically decreasing function of $\psi$. The objective function is non-standard because the decision of the undertaking is non-standard. The usual assumptions of profit or shareholder value maximisation are meaningful if certain stakeholders are exogenously assigned the shareholder status and the undertaking makes decisions on prices or quantities, not on anyone's shareholder status. But if the undertaking decides 
who the shareholders are and how many of them there should be, one must assume another objective function. Would the bank pursue an infinite ROE by issuing no equity at all, even though there would be no shareholders who would benefit from profits? Or would it have a more complicated objective function? Possibly it might maximise a weighted average of total profit and ROE, but how would the weights be determined?

Although the model is strongly inspired by the original Diamond-Dybvig model, there are a number of differences. The original model assumed no other funding instrument than deposits. All consumers were identical and risk averse. The return of investments held till maturity was risk-free and materialised at the end of the project. Moreover, the bank had got no signalling device. Assets could be liquidated without destroying them, and nothing but the revenue was lost. In this paper there are two kinds of financial contracts, two kinds of investors, and the bank actively uses a signalling device. Moreover, the return on investments is random, possible revenue materialises at an early stage and assets cannot be liquidated prematurely at their full value.

\section{Solving the model - threshold dividend}

Now, it is assumed that the run will take place with certainty unless an exogenously given relatively high minimum dividend $\eta_{g}$ is paid. This value may be determined by dividends paid by the bank in the past, or by other (possibly foreign) banks' standard practices. Paying a higher dividend would not affect depositors' behaviour, but paying less would trigger a run. Technically, such a threshold dividend could exist even in a full information setting, and all the mathematics of the model would remain unchanged. If depositors reacted to a low dividend by panicking even under full information, the dividend would become a mere "sunspot" in the sense that there would be no logical connection between the dividend and the reaction. Financiers would have already observed the soundness of the bank anyway, and they would not try to extract additional information from the dividend.

The analysis is restricted to cases where $\eta_{g} E<D-\lambda \Omega N$; hereafter this condition is called the indebtedness condition. If this condition is not satisfied the amount of deposits and other types of short maturity debt after normal withdrawals is so small that the bank would need more currency to pay the expected dividend than to pay its panicking depositors in a run. Such an institution could exist, but nobody would call it a bank. Whenever the share of depositors who are potentially subject to a liquidity shock $(\Omega)$ is large enough, the bank must collect deposits, and the indebtedness condition must be satisfied. 
It is easy to demonstrate that the bank tries to avoid the run at any cost.

Proposition 1: If the indebtedness condition is valid, not paying the dividend $\eta_{g}$ is never a less costly alternative than paying it.

If the bank pays normal withdrawals and interest rates at stage four, but the dividend is not paid, a run occurs. In this case the liquidation cost equals

$$
\begin{aligned}
& \operatorname{Max}\left\{\left[(1+\delta) D-L-\alpha^{\prime} I\right](1-Z) / Z, 0\right\} \\
& \alpha^{\prime} \in(\alpha, 0), \text { depending on the return on investments. }
\end{aligned}
$$

The corresponding liquidation cost, when the run is prevented by paying the dividend, is

$$
\operatorname{Max}\left\{\left[\eta_{g} E-L-\alpha^{\prime} I+\Omega \lambda N+\delta D\right](1-Z) / Z, 0\right\}
$$

(3) cannot be greater than (2) if the indebtedness condition is satisfied.

$$
\begin{aligned}
& \eta_{g} E+\Omega \lambda N<D \\
& \Leftrightarrow \eta_{g} E-L-\alpha^{\prime} I+\Omega \lambda N+\delta D<(1+\delta) D-L-\alpha^{\prime} I
\end{aligned}
$$

If the bank is unable to pay all the depositors, the loss caused by not paying the dividend equals $I(1-Z)$, which is the highest liquidation cost that could be observed. No alternative can be more costly.

\section{QED}

At stage 2 the bank must choose how much currency to hold. Because a significant part of depositors will withdraw anyway $(\Omega \lambda>0)$, cases where no currency hoarding or liquidations would be needed can be ruled out. The mere return on assets cannot be high enough to cover withdrawals because by assumption $\alpha<\Omega \lambda$. The bank has got the following options at stage 2 .

1) It may hoard enough currency to be able to pay the dividend, interest on deposits and withdrawals without liquidating assets even when the investment yields no return. In this case, the amount of currency must satisfy

$$
L \geq \delta D+\eta_{g} E+N \lambda \Omega
$$


2) Alternatively, it may hoard enough currency to be able to pay the dividend without liquidating assets if and only if the return on assets is normal.

$$
\delta D+\eta_{g} E+N \lambda \Omega>L \geq \delta D+\eta_{g} E-\alpha I+N \lambda \Omega
$$

3) It may hold a very limited amount of currency, implying that some investments will be liquidated even in the normal state.

$$
L<\delta D+\eta_{g} E+N \lambda \Omega-\alpha I
$$

Making investments that need to be liquidated in any case is not rational because by assumption $\alpha<(1-Z)$, and the third alternative can be ignored. It is more interesting to analyse whether the bank would decide to prepare itself to pay the expected payments even in the bad state without liquidations.

Proposition 2: The optimal amount of currency hoarded at stage two is barely sufficient for dividend and other payments at stage four under normal asset return and no liquidations.

\section{PROOF: See Appendix 1}

The result is basically intuitive. Because currency yields no return, the bank does not want to keep any extra balances. The bank is always prepared to make all the necessary payments at least in the good state. If the bad state were relatively likely (i.e. theta low), it would find it optimal to hoard enough currency to be prepared even for the bad state, but by assumption, theta is close to 1 .

Everyone behaves rationally, given the strategy of the counterparty. If the dividend is not paid, each depositor understands the bank is in trouble (proposition 1). The quasi-sunspot makes every depositor believe everybody else tries to withdraw, although it may be too late to join the run. The indebtedness condition implies that if the bank cannot pay the dividend, it certainly cannot pay all the panicking depositors in the run. Therefore, a rational depositor reacts to non-payment by running to the withdrawal desk. This behaviour is consistent with the beliefs of other depositors and the outcome is a Perfect Bayesian Equilibrium. Nevertheless, the equilibrium is not unique because a very large number of potential threshold dividends would satisfy the same equilibrium criteria.

Proposition 3: Let the indebtedness condition be valid. The expected value of the total loss $\psi$ increases if the amount of equity capital increases at the cost of deposits. 


\section{PROOF: See Appendix 2.}

This result basically implies that equity is expensive. Paying the dividend under normal circumstances is expensive because the bank must hoard non-productive currency. In most cases this means loss of investment revenue. If the bad state materialises, the bank tries to save what can be saved and mimic normal profitability by liquidating assets. It tries to maintain the dividend and to create an illusion of normal profitability. This is costly, and the more equity capital has been issued, the more liquidations are needed in the bad state to pay the dividend expected by the market.

\section{Optimising the dividend}

\subsection{Assumptions}

It can be demonstrated that in a less extreme structure the optimal dividend is higher if bank assets earn the expected return. Moreover, the bank prefers to be thinly capitalised. Now, the bank can choose any dividend $\eta$ it prefers; there is no specific threshold value. If the dividend is low, the probability of the run increases. A low dividend induces the most nervous depositor not subject to a liquidity shock to withdraw. Those who know this individual in person observe the combination of withdrawing and lack of liquidity shock. This observation makes them believe a run has begun, and they follow suit. Those who in turn know these 'contaminated' depositors will join the run, and the panic spreads in the social network. The bank knows how the probability of a run depends on the dividend. Increasing the dividend reduces the probability of run $(P)$.

$$
P=P(\eta) ; 0 \leq P \leq 1 ; P^{\prime}<0 ; P^{\prime \prime}>0
$$

After stage one, investors cannot observe any other management decisions than the dividend. Parameters $\Omega$ and $Z$ are not known by investors. The bank, instead, can observe these parameter values, even though it does not know before stage three whether investments were a success or a failure. Parameters $\alpha$, $\lambda$ and $\theta$ are known by all.

\subsection{Analytical results}

Proposition 4; The optimal dividend is higher if bank investments yield the return $\alpha$ than if they do not. 
PROOF: See Appendix 3

This result is probably clarified by Figure I. The marginal cost of paying dividends is zero until dividends must be financed at the margin by liquidating assets, which happens at a lower level of dividends if investments have generated no revenue to be distributed. In the good state the cost of paying dividends is zero until $\eta=[L+\alpha I-\Omega \lambda-\delta D] / E$. In the bad state the marginal cost is zero until $\eta=[L-\Omega \lambda-\delta D] / E$. Beyond this point the marginal cost of dividend payments is determined by the loss caused by premature liquidations. The benefit from avoiding the run is marginally lower in the bad state than in the good state with each dividend; some costly liquidations are needed in the bad state anyway to finance any given dividend, implying that there is less to lose if a run takes place and the bank is forced to liquidate its whole balance sheet. The marginal cost curve and the marginal benefit curve of dividend payments cross at a lower level of dividends in the bad state. There can be no cases where the amount of currency chosen by the bank at stage 2 would be insufficient to enable the dividend payment that will be made in the good state; it is always cheaper to be prepared and to keep enough currency than to buy assets that will be liquidated anyway. Hence, marginal benefit curve 2 in cannot prevail; the bank would hoard more currency, shifting the point $(L+\alpha I-\Omega \lambda-\delta D) / E$ to the right. Thus, the dividend is indicative of the state of the bank and not a pure sunspot.

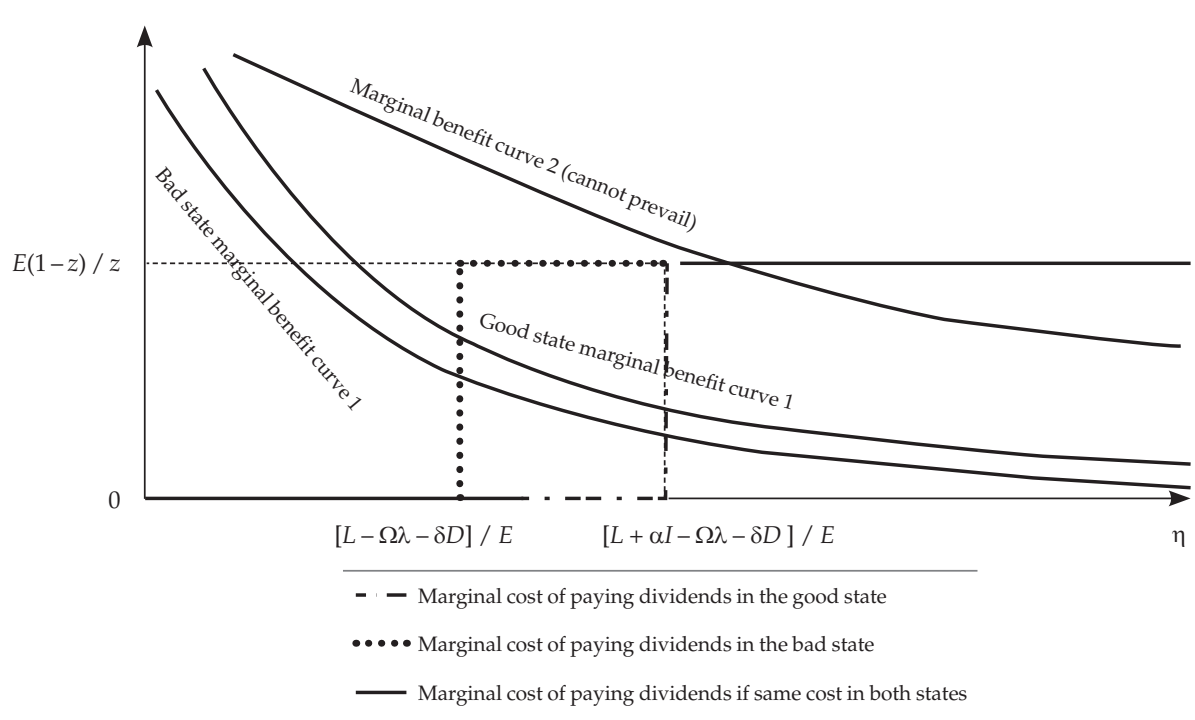

Figure 1. Marginal cost an benefits of dividends. 


\subsection{Simulations}

The bank knows its customers well enough to know that the probability of the run is

$$
r=-2\left[\frac{\eta-\delta}{1-\delta}\right]^{1 / 20}+\left[\frac{\eta-\delta}{1-\delta}\right]^{1 / 10}+1 \text { when } \delta<\eta<1
$$

If $\delta \geq \eta=>r=1$; If $\eta \geq 1=>r=0$.

When $\eta=\delta$, the run is a certainty but the marginal effect of $\eta$ on $r$ is infinitely strong. The marginal impact weakens very fast with higher values of $\eta$. When $\eta=1$, the marginal impact is zero and $r=0$. This functional form is basically ad hoc, but it satisfies the conditions (8). Variables not observed by depositors $(\Omega$ and Z) are chosen for each simulation separately from the following distributions.

$$
\left.\begin{array}{c}
Z=\operatorname{mnd} 1(1-\theta) /(1-\theta+\alpha \theta)+(1-\operatorname{rnd} 1)(1-\alpha) \\
\Omega=\alpha / \lambda+0.95^{*} \operatorname{rnd} 2(1-\alpha / \lambda)
\end{array}\right\}
$$

Where $r n d 1$ and $r n d 2$ are iid distributed random draws from an even distribution between 0 and 1 . The distribution of $Z$ covers values that satisfy the criteria $(1-Z)>\alpha$ and $\theta>(1-Z) /(1-Z+\alpha Z)$. The distribution of omega covers most of the values that satisfy the condition $1>\Omega>\alpha / \lambda$. (See section 2 )

Eight different combinations of observable parameter variables were tested. Each combination was simulated 200 times with different values of $Z$ and $\Omega$ determined by (10). The deposit rate was determined mechanically as $\delta=\alpha / 3$. With this rule the bank never promises more interest payments on deposits than what investments would yield under favourable circumstances. The algorithm tested every possible combination of integer values for balance sheet variables $(I, L, E, D)$ separately. The bank should have some equity and the lowest amount of equity tested in these simulations was +1 . A special subroutine searched an optimal value of dividends in both the good state and the bad state for each possible combination of balance sheet variables. The number of investors is 200 in each simulation.

The algorithm minimises

$$
E(\psi)=H(1-Z)+\theta \alpha L
$$


Where $H$ is the amount of investments liquidated at stage four. The amount of liquidations is determined either by the need of currency or by the amount of assets, whichever condition is binding. If a run takes place

$$
H=\operatorname{Min}\left\{I,\left(\eta E+(1+\delta) D-\alpha^{\prime} I-L\right) / Z\right\}
$$

If no run takes place

$$
H=\operatorname{Min}\left\{I,\left(\eta E+\delta D+N \Omega \lambda-\alpha^{\prime} I-L\right) / Z\right\}
$$

where $\alpha^{\prime}$ is either $\alpha$ or 0 , depending on the state of bank investments.

Results are summarised in Table 1. The following regularities can found in the results.

- In every case the optimal amount of equity is one, which was exogenously set as the absolute minimum. There is no exception in the whole set of $200 * 8=1600$ simulation rounds.

- In each case the average bad state dividend is lower than the average good state dividend, implying that the dividend is indicative of the state of the bank.

- The average return of depositors who hold their investments till maturity (non-withdrawer) is higher than the return of those who experience a liquidity shock and withdraw at stage four (withdrawers).

\begin{tabular}{|c|c|c|c|c|c|c|c|c|}
\hline Simulation set $\mathrm{nr}$ & 1 & 2 & 3 & 4 & 5 & 6 & 7 & 8 \\
\hline Observable variables & $\begin{array}{l}\alpha=0.4 ; \\
\lambda=0.5\end{array}$ & $\begin{array}{l}\alpha=0.2 ; \\
\lambda=0.5\end{array}$ & $\begin{array}{l}\alpha=0.1 ; \\
\lambda=0.5\end{array}$ & $\begin{array}{l}\alpha=0.2 ; \\
\lambda=0.3\end{array}$ & $\begin{array}{l}\alpha=0.1 ; \\
\lambda=0.3\end{array}$ & $\begin{aligned} \alpha & =0.15 ; \\
\lambda & =0.2\end{aligned}$ & $\begin{array}{l}\alpha=0.1 ; \\
\lambda=0.2\end{array}$ & $\begin{aligned} \alpha & =0.05 ; \\
\lambda & =0.2\end{aligned}$ \\
\hline $\begin{array}{l}\text { Average dividend } \\
\text { in bad state }\end{array}$ & 0.14 & 0.35 & 0.16 & 0.15 & 0.16 & 0.17 & 0.17 & 0.17 \\
\hline $\begin{array}{l}\text { Maximum dividend } \\
\text { in the bad state }\end{array}$ & 0.20 & 0.25 & 0.28 & 0.26 & 0.27 & 0.27 & 0.27 & 0.27 \\
\hline $\begin{array}{l}\text { Average dividend } \\
\text { in good state }\end{array}$ & 0.47 & 0.56 & 0.64 & 0.57 & 0.69 & 0.65 & 0.70 & 0.74 \\
\hline $\begin{array}{l}\text { Minimum dividend } \\
\text { in good state }\end{array}$ & 0.24 & 0.21 & 0.19 & 0.26 & 0.23 & 0.25 & 0.26 & 0.27 \\
\hline Average equity $E$ & 1.00 & 1.00 & 1.00 & 1.00 & 1.00 & 1.00 & 1.00 & 1.00 \\
\hline
\end{tabular}

Table 1. Simulation results 


\begin{tabular}{lcccccccc}
\hline \multicolumn{1}{c}{ Simulation set nr } & 1 & 2 & 3 & 4 & 5 & 6 & 7 & 8 \\
\hline Average investments I & 144 & 149 & 146 & 173 & 171 & 183 & 182 & 180 \\
$\begin{array}{l}\text { Average non- } \\
\text { withdrawer's return }\end{array}$ & 0.24 & 0.12 & 0.06 & 0.12 & 0.06 & 0.09 & 0.06 & 0.03 \\
$\begin{array}{l}\text { Average withdrawer's } \\
\text { return }\end{array}$ & 0.12 & 0.06 & 0.03 & 0.06 & 0.03 & 0.04 & 0.03 & 0.01 \\
\hline
\end{tabular}

Average withdrawers' return = return of a depositor who withdraws at stage four in any case; Average nonwithdrawer's return = return of a depositor who does not withdraw before stage five unless there is a run or a personal liquidity shock.

$N=200$

$\delta=0.3^{*} \alpha ; \theta=0.995$

\section{A fully transparent bank}

If the bank were fully transparent, the dividend should have no value as a signal because counterparties could observe the return on investments. It would be difficult to defend the assumption that a dividend cut would cause panic. If anything, creditors would be worried if they observed that the solvency of the bank is weakened by excessive dividends. At stage 4, financiers would base their decisions on withdrawals on the return on investments. If the return is weak, all depositors withdraw, and the loss due to premature liquidations is

$$
\operatorname{Max}\{[(1+\delta) D-L](1-Z) / Z, 0\}
$$

The probability of the run would not depend on the funding structure. Obviously, the value of (14) is minimised if $\mathrm{D}$ is as low as possible. Hence, equity capital would be inexpensive because each financier participating in the run causes losses and shareholders cannot withdraw prematurely. Having issued equity instead of debt would protect the bank against liquidations.

\section{The model and previous empirical literature}

Lintner (1956) noticed that many companies maintain a stable dividend rate. They react sluggishly to new higher levels of profit and minimise the risk of having to drastically cut dividends. Garrett and Priestley (2000) found that unexpected increases in permanent earnings affect the current dividend whereas negative shocks have no observable impact, consistently with the hypothesis of 
strong aversion to dividend cuts. Avoiding dividend cuts may have to do with signalling; at least this smoothing has been much more commonplace in the U.S. than in Hong Kong, where the institutional environment probably reduces the need for signalling (Chemmanur et al., 2010). Bond issuing rated companies are significantly more likely to smooth their dividends than non-rated firms, probably because bond issuers need to avoid sending negative signals, such as dividend cuts (Aivazian et al., 2006). Dividends have more information content in periods of economic adversity (Bozos et al., 2011), i.e. when the risk of bank runs is heightened.

Some empirical studies concentrate on banks' dividend policies. The findings of Casey and Dickens (2000) and Newman et al., (2002) corroborated the hypothesis that large U.S. banks prefer paying stable dividends. Theis et al., (2010) found that U.S. banks tried to maintain stable dividends even during the recent financial crisis; in fact, no other correlate of dividends had as much explanatory power. Forti and Schiozer (2012) found that banks are more likely to pay high dividends if they rely on information-sensitive institutional depositors, and this behaviour became more pronounced during the financial crisis. However, there seem to be no detailed comparative studies on differences between banks' and non-banks' dividend policies.

Maintaining stable dividends during difficult times would be almost useless as a signalling device if no attention were paid to dividends. The stock market reacts positively to dividend increases of bank holding companies (Filbeck \& Mullineaux, 1999). If a bank announces dividend cuts, this often induces negative abnormal returns in non-announcing banks, presumably because investors interpret dividend cuts as signals on debtors' financial problems (Bessler \& Nohel, 2000).

Empirical evidence suggests that both fundaments and contagion play a role in bank runs, consistently with the assumptions made in section two. Weak banks were more likely to suffer from loss of deposits in the Argentine crisis (McCandless et al., 2003). Depositor groups have reacted to each others' withdrawals (Starr \& Yilmaz, 2007) and the decision to withdraw may spread from individual to individual in the social network (Iyer \& Puri, 2012). Both withdrawals from failing banks and contagious runs can be identified in the Great Depression (Saunders \& Wilson, 1996). A run can be triggered by signals that might even be interpreted as reassuring: retail depositors paradoxically started to queue at branch offices of Northern Rock when the Bank of England had announced its intention to support the bank (see e.g. Shin, 2009). In real life, banks have reacted to liquidity risk by increasing their cash holdings (Sawada, 2010). 


\section{Discussion}

Industry practitioners tend to argue that equity capital is expensive for banks. This claim contradicts the Modigliani-Miller irrelevance theorem. This paper presents a potential explanation to this paradox. The explanation is based on banks' vulnerability to deposit runs, which is a problem specific to credit institutions. It is argued that the viability of opaque banks with short maturity debt and illiquid assets depends on signalling. If the bank reveals its weak position by cutting dividends, suspicious counterparties withdraw funding. Such dividend cuts may be particularly dangerous if financiers observe any signs of adverse macroeconomic developments, i.e. when low or negative asset returns become more likely. These nervous creditors may include both money market counterparties and retail depositors. Spencian signalling by paying dividends is possible because distributing non-existent profits is costly or even impossible. In real life, the bank might also signal its good state with share repurchases instead of dividend payments, provided these repurchases are publicly observable.

In real life a high dividend may even be an alarming signal; if the bank distributes more to shareholders than what it used to, this might be interpreted as a sign of "cashing out", especially if this happens during a recession. No bank would want to signal its lack of good investment possibilities during bad times by paying exceptionally high dividends. Araujo et al., (2011) have suggested a complicated U-shaped relationship between firm performance and optimal dividends; a company may also be unwilling to pay dividends if it is has got excellent investment possibilities. Investors' tendency to underestimate the impact of leverage may also affect the cost of capital (Levati et al., 2012).

The model has at least one obvious policy implication. If the public observes clear symptoms of a recession, it is reasonable to restrict banks' dividend payments. If such a regulation is enforced and applies to all banks, dividend cuts tell nothing about the profitability of any particular institution, and bank solvencies could be enhanced with retained earnings without bank-specific adverse signalling effects.

In some cases the bank may be able to choose how opaque to be. The bank would probably prefer to keep at least the return on its assets opaque; with this opaqueness, not every downturn causes panic and forces the bank to liquidate assets at loss. The bank might survive for a while even when it knows it cannot pay all the depositors at stage five. Kaplan (2006) proves that in a slightly different Diamond-Dybvig type of model, the bank may or may not prefer to keep the return on its assets secret.

If investors are able to observe the true leverage of the bank, minimising the amount of capital in order to be able to maintain a high and stable dividend 
yield irrespective of profitability would be an inefficient strategy. Counterparties would pay attention to the sum of dividends relative to the volume of operations rather than to the dividend per share, and choosing a weaker capitalisation would not make it easier to send reassuring signals. Thus, the model yields the following empirical prediction. Complex banking organisations, where the true leverage cannot be accurately estimated by outsiders, are more likely to consider equity capital expensive. A bank with simple operations, a transparent balance sheet and no off-balance sheet risks cannot mimic high profitability by choosing an extreme leverage and paying a high and steady return on a tiny equity capital. Interestingly, minimising the capital base seems to have become more commonplace when banking has become more complicated. In the past, before derivatives and off-balance sheet vehicles became commonplace, banks were much less leveraged than what they are now (See e.g. Åhman, 1943 p. 70; Thies \& Gerlowski, 1993; Saunders \& Wilson, 1999.) High capitalisation ratios found in bank balance sheets from past decades probably give a reasonably accurate idea about the true leverage of banks in our grandparents' time. Obviously early and mid $20^{\text {th }}$ century banks did not consider equity highly expensive. There may be several explanations for this change in the way of thinking, and different explanations are not necessarily mutually exclusive.

\section{References}

Admati, A. R., DeMarzo, M. P., Hellwig M. F., \& Pfleiderer, P. (2010). Fallacies, irrelevant facts and myths in the discussion on capital regulation: Why bank equity is not expensive. The Rock Center for Coprorate Governance at Stanford University working paper series, 2063.

Åhman, G. (1943). Strukturförändringar i affärsbankernas rörelse (In Swedish: Structural changes in commercial banks' business). Ekonomiska samfundets tidskrift, 58, 54-102.

Aivazian, V. A., Booth, L., \& Cleary, S. (2006). Dividend smoothing and debt ratings. The Journal of Financial and Quantitative Analysis, 41, 439-453.

Al-Yahyaee, K. H., Pham, T M., \& Walter, T. S. (2011). The information content of cash dividend announcements in a unique environment. Journal of Banking and Finance 35, 606-612.

Araujo, A. Moreira, H., \& Tsuchida, M. (2011). Do dividend changes signal future earnings? Journal of Financial Intermediation, 20, 117-134.

Bessler, W., \& Nohel, T. (2000). Asymmetric information, dividend reductions and contagion effects in bank stock returns. Journal of Banking and Finance, 24, 1831-1848. 
Bhattacharya, S. (1979). Imperfect information, dividend policy and "the bird in the hand" fallacy. The Bell Journal of Economics, 10, 259-270.

Bozos, K., Nikopoulos, K., \& Ramgandhi, G. (2011). Dividend signaling under economic adversity: evidence from the London Stock Exchange. Review of Financial Analysis, 20, 364-374.

Calomiris, C. W., \& Kahn, C. M. (1991). The role of demandable debt in structuring optimal banking arrangements. American Economic Review, 81, 497-513.

Casey, M. K., \& Dickens, R. N. (2000). The effects of tax and regulatory changes on commercial bank dividend policy. The Quarterly Review of Economics and Finance, 40, 279-293.

Chemmanur, T. J., He, J., Hu, G., \& Liu, H. (2010). Is dividend smoothing universal? New insights from a comparative study of dividend policies in Hong Kong and the U.S. Journal of Corporate Finance, 16, 413-430.

Diamond, D. W. (1984). Financial intermediation and delegated monitoring. Review of Economic Studies, 51, 393-414.

Diamond, D. W., \& Dybvig, P. H. (1983). Bank Runs, Deposit Insurance, and Liquidity. Journal of Political Economy, 91, 401-419.

Diamond, D. W., \& Rajan, R. (2001). Liquidity risk, liquidity creation and financial fragility: a theory of banking. Journal of Political Economy, 109, 287-327.

Filbeck, G., \& Mullineaux, D. J. (1999). Agency costs and dividend payments: The case of bank holding companies. The Quarterly Review of Economics and Finance, 39, 409-418.

Forti, C. A. B., \& Schiozer, R. F. (2012). Bank Dividends and Signaling to InformationSensitive Depositors. Working Paper. Retrieved from http:/ / papers.ssrn. com/sol3/papers.cfm?abstract_id=2139725

Garrett, I., \& Priestley, R. (2000). Dividend Behavior and Dividend Signaling. The Journal of Financial and Quantitative Analysis, 35, 173-189.

Hanson, S. G., Kashyap, A. K., \& Stein, J. G. (2011). A Macroprudential Approach to Financial Regulation. Journal of Economic Perspectives, 25, 3-28.

Hirtle, B. (2006). Stock market reaction to financial statement certification by bank holding company CEOs. Journal of Money, Credit and Banking, 38, 1263-1291.

Iannotta, G. (2006). Testing for opaqueness in the European banking industry: evidence from bond credit ratings. Journal of Financial Services Research, 30, 287-309.

Iyer, R., \& Puri, M. (2012). Understanding bank runs: The importance of depositor-bank relationships and networks. American Economic Review, 102, 1414-1445.

Kaplan, T. R. (2006). Why banks should keep secrets. Economic Theory, 27, 341357. 
Keeley, M. C. (1990). Deposit insurance, risk and market power in banking. American Economic Review, 80, 1183-1200.

Levati, M. V., Qiu, J., \& Mahagaonkar, P. (2012). Testing the Modigliani-Miller theorem directly in the lab. Experimental Economics, 15, 693-716.

Lintner, J. (1956). Distribution of incomes of corporations among dividends, retained earnings and taxes. American Economic Review 46, Papers and proceedings of the sixty-eighth annual meeting of the American Economic Association, 97-113.

McCandless, G., Gabrielli, M. F., \& Rouillet, M. J. (2003). Determining the causes of bank runs in Argentina during the crisis of 2001. Revista de Análisis Económico, 18, 87-102.

Miller, M. H., \& Modigliani, F. (1961). Dividend Policy, Growth and the Valuation of Shares. Journal of Business 34, 411-433.

Modigliani, F., \& Miller, M. H. (1958). The Cost of Capital, Corporation Finance and the Theory of Investment. American Economic Review, 48, 261-297.

Morgan, D. P. (2002). Rating banks: risk and uncertainty in an opaque industry. American Economic Review, 92, 874-888.

Newman, J. A., Dickens, R. N., \& Casey, K. M. (2002). Bank Dividend Policy: Explanatory Factors. Qurarterly Journal of Business and Economics, 41, 3-12.

OECD (2010). Economic Surveys. Euro area 2010, OECD Publishing. Retrieved from http:/ /dx.doi.org/10.1787/eco_surveys-euz-2010-en

Saunders, A., \& Wilson, B. (1996). Contagious bank runs: Evidence from the 1929-1933 period. Journal of Financial Intermediation, 5, 409-423.

Saunders, A., \& Wilson, B. (1999). The impact of consolidation and safety-net support on Canadian, US and UK banks 1893-1992. Journal of Banking and Finance, 23, 537-571.

Sawada, M. (2010). Liquidity risk and bank portfolio management in a financial system without deposit insurance: empirical evidence from prewar Japan. International Review of Economics and Finance, 19, 392-406.

Shin, H. S. (2009). Reflections on Northern Rock: The Bank run that heralded the global financial crisis. Journal of Economic Perspectives, 23, 101-119.

Starr, M. A., \& Yilmaz, R. (2007). Bank runs in emerging-market economies: evidence from Turkey's Special Finance Houses. Southern Economic Journal, 73, 1112-1132.

Theis, J., Yesilyaprak, A., Jauregui, A., \& Dutta, A. (2010). Bank holding company dividend policy: changed by recession? Paper presented at 2010 Southwest Decision Sciences Institute Conference in Dallas, Texas

Thies, C., \& Gerlowski, D. (1993). Bank capital and bank failure 1921-1932: Testing the White hypothesis. The Journal of Economic History, 53, 908-914. 


\section{Appendix 1}

Proof of Propositon 2

If the bank hoards enough currency to pay the dividend $\eta_{\mathrm{g}}$ in any state, $E(\psi)$ is the multiple of the required amount of currency in the bad state $\left(\delta D+\eta_{g} E+\right.$ $N \lambda \Omega)$, the opportunity cost of one unit of currency in the good state $(\alpha)$ and the probability of receiving the normal return $(\theta)$. Liquidation costs cannot materialise and the value of $Z$ is irrelevant.

If the bank hoards enough currency to be able to pay dividends without liquidations in the good state only, the total cost is the sum of two components.

- The expected value of the opportunity cost of holding currency is $\alpha \theta\{\delta D+$ $\left.\eta_{g} E-\alpha I+N \lambda \Omega\right\}$.

- In the bad state it must liquidate assets to get the sum I $\alpha$ not received from investments. The expected value of the cost of asset liquidation, in case the dividend can be paid by liquidating, is $(1-\theta) \alpha I(1-Z) / Z$. If there are not sufficient assets to cover the payment needs, the cost is the maximal liquidation loss $I(1-Z)$, which must be less.

In expected value terms the total cost of being prepared to pay dividends without liquidations only in the good state is lesser than the cost of having enough currency to make payments in any state at least if

$$
\begin{gathered}
\theta \alpha\left(\delta D+\eta_{g} E-\alpha I+N \lambda \Omega\right)+(1-\theta) \alpha I(1-Z) / Z<\theta\left(\delta D+\eta_{g} E+N \lambda \Omega\right) \alpha \\
\Leftrightarrow \theta>(1-Z) /[1-Z+\alpha Z]
\end{gathered}
$$

By assumption, this condition holds. There cannot be cases where the optimal value of $L$ lies between $\delta D+\eta_{g} E-\alpha I+N \lambda \Omega$ and $\delta D+\eta_{g} E+N \lambda \Omega$. With such values of $L$ the derivative of $\psi$ with respect to $L$ would be

$$
\alpha \theta-(1-\theta)(1-Z) / Z \Rightarrow \frac{\partial^{2} \psi}{\partial L^{2}}=0
$$

The expression (1.2) is a sufficient but not a necessary condition because the bank may run out of assets, which limits the cost in the bad state, making hoarding of currency for the bad state less useful.

QED 


\section{Appendix 2}

Proof of Proposition 3

Because $E=N-D$ and $I=N-L$, the necessary amount of currency is

$$
\begin{aligned}
& L=\delta D+\eta_{g}(N-D)-\alpha(N-L)+N \lambda \Omega \\
& =>L=\left[\eta_{g} N+\delta D+N \lambda \Omega-D \eta_{g}-\alpha N\right] /(1-\alpha)
\end{aligned}
$$

The expected value of the cost of hoarding this amount of currency is the multiple of $\theta, \alpha$ and expression (2.1).

The amount of investment revenue that does not materialise in the bad state is $I \alpha$. The cost of liquidating enough investments to get this missing sum is $I \alpha(1-Z) / Z$, and the probability of this occurring is $(1-\theta)$. Because $I=N-L$, and because $L$ is determined by expression (2.1), the expected value of this cost component is

$$
\begin{aligned}
& \operatorname{Min}\left[(1-\theta) \alpha[(1-Z) / Z]\left[N-\left(\eta_{g} N+N \lambda \Omega+\delta D-D \eta_{g}-\alpha N\right) /(1-\alpha)\right],\right. \\
& (1-Z) I]
\end{aligned}
$$

The cost $(1-Z) I$ is incurred if the bank is unable to make all the payments even if it liquidates all the investments.

In the good state the cost consists of the opportunity cost of not making investments, which equals $L \alpha$. The probability of this occurring is $\theta$. Because the amount of currency is determined by (2.1), the expected value of this cost is

$$
\theta \alpha\left[\eta_{g} N+\delta D-D \eta_{g}-\alpha N+N \lambda \Omega\right] /(1-\alpha)
$$

If the sum of (2.2) and (2.3) is differentiated with respect to $D$, one gets either

$$
-\theta \alpha\left(\eta_{g}-\delta\right) /(1-\alpha)<0
$$

(if the bank is unable to pay the dividend in the bad state and nothing but the good state matters at the margin), or

$$
\frac{\left(\eta_{g}-\delta\right)(1-\theta-Z) \alpha}{(1-\alpha) Z}
$$


The expression (2.5) is negative iff $1-\theta-Z<0$. The lowest value of $\theta$ in banks not able to make all payments without liquidations in the bad state is $(1-Z)$ / $(1-Z+\alpha Z)$. With this minimal value of $\theta$

$$
1-\theta-Z=1-Z-(1-Z) /(1-Z+\alpha Z)<0 \Leftrightarrow 1-1 /[1-Z(1-\alpha)]<0
$$

Because $0<Z(1-\alpha)<1$, (2.6) holds with certainty. And because the derivative of (2.5) with respect to $\theta$ is negative, (2.5) cannot become positive with higher values of $\theta$. Therefore costs decrease when the deposit base expands at the cost of equity capital.

\section{QED}

\section{Appendix 3. Proof of Proposition 4}

Terminology and notation; Marginal benefit from dividends = the derivative of -(loss caused by the run) $P$

with respect to $\eta$, where $P$ is the probability of the run.

$\eta_{a}=$ dividend in the good state (investments yield $\alpha$ )

$\eta_{b}=$ dividend in the bad state (no return on investments)

And * denotes optimal dividend.

Sub-proposition 1: Optimal $\eta_{a}=[L+\alpha I-\Omega \lambda-\delta D] / E$

PROOF: Iff $\eta a<[L+\alpha I-\Omega \lambda-\delta D] / E$, the good state marginal cost of paying more dividends is zero at stage three because there is no alternative use for excess currency. The marginal benefit is always positive. Therefore the optimal dividend in the good state satisfies $\eta_{a}^{*} \geq[L+\alpha I-\Omega \lambda-\delta D] / E$

It is not possible to find cases where $\eta_{a}^{*}$ is wholly or partly paid by liquidating assets because it is never profitable to make investments that need to be liquidated anyway.

\section{QED}

Subproposition 2: If $\eta_{b}=\eta_{a}=[(L+\alpha I-\Omega \lambda N-\delta D) / E]-$, the marginal cost of paying dividends in the bad state is $E(1-Z) / Z .^{2}$

2 Notation: $X-=$ infinitesimally smaller than $X$ 
PROOF: The sub-proposition 1 implies that this bad state dividend cannot be financed without liquidations. $=>$ The marginal cost of increasing the dividend in the bad state equals $E(1-Z) / Z$.

\section{QED}

\section{Subproposition 3}

With $\eta_{a}^{*}$ the marginal benefit of dividends in the good state $<E(1-Z) / Z$.

PROOF: If the marginal benefit of the dividend in the good state were higher than $E(1-Z) / Z$, it would be rational to increase the dividend even by liquidating because the benefit would exceed the cost.

The marginal cost of increasing the dividend na by hoarding more currency is $\alpha \mathrm{E}$ in the good state. This is less than $E(1-Z) / Z$ because by assumption $(1-Z)>\alpha$ and $(1-Z) / Z>(1-Z)$. Therefore, whenever the marginal benefit exceeds $E(1-Z) / Z$, it would have been optimal to hoard more currency.

The possibility of the bad state does not change the conclusion. Having more currency cannot increase the cost, and does not make currency hoarding less attractive. Therefore a rational bank hoards currency until optimal $\eta_{a}^{*}<E(1-Z) / Z$.

\section{QED}

Subproposition 4 The good state marginal benefit of increasing the dividend is higher or as high as in the bad state if $\eta_{b}=\eta_{a}$.

PROOF: In both cases the impact on the probability of the run is the same. In the bad state there are less assets because some of them have already been liquidated anyway in order to pay the dividend. Therefore there are less assets that might be lost in a run, decreasing the cost.

\section{QED}

Subpropositions 1 and 2 imply that the marginal cost of increasing $\eta_{b}$ is $E(1-Z) / Z$ if $\eta_{b}=\eta_{a}^{*}-$. Subpropositions 3 and 4 imply that when $\eta_{b}=[(L+\alpha I-$ $\Omega \lambda N-\delta D) / E]-$, the marginal benefit from increasing the dividend is less than $E(1-Z) / Z$. Therefore the marginal cost is higher than the marginal benefit, and it is rational to reduce the dividend. Therefore $\eta_{a}^{*}>\eta_{b}^{*}$.

QED. 
